\title{
Whether Cash Dividend Policy of Chinese Listed Companies Caters to Investors' Preference
}

\author{
Xiaotong Zhan \\ Jinan University, Guangzhou, China \\ Email: zhanxt1991@163.com
}

How to cite this paper: Zhan, X. T. (2016). Whether Cash Dividend Policy of Chinese Listed Companies Caters to Investors' Preference. Journal of Financial Risk Management, 5, 161-170.

http://dx.doi.org/10.4236/ifrm.2016.53016

Received: July 7, 2016

Accepted: September 19, 2016

Published: September 22, 2016

Copyright $\odot 2016$ by author and Scientific Research Publishing Inc. This work is licensed under the Creative Commons Attribution International License (CC BY 4.0).

http://creativecommons.org/licenses/by/4.0/

(c) (†) Open Access

\begin{abstract}
From the perspective of catering theory of dividends, this paper studies the relationship between cash dividend policy and investors' preference, and also the relationship between cash dividend policy and enterprise features, making use of 2008-2014 data of listed companies in Shanghai and Shenzhen Exchanges. Our research discovers that rising corporate profitability and scale increase willingness to pay cash dividends of listed companies, whereas increasing investment opportunities significantly reduce the cash dividend payment. We create the variables of propensity to pay and dividend premium. The 2008-2014 dividend premium in Shanghai Exchange is negative and is negatively correlated with propensity to pay, showing that cash dividend policy still does not cater to investors' preference after the completion of no-tradable shares reform.
\end{abstract}

\section{Keywords}

Cash Dividend Policy, Catering Theory of Dividends, Enterprise Features, Propensity to Pay, Dividend Premium

\section{Introduction}

U.S. financial expert Miller and economist Modigliani (Miller \& Modigliani, 1961) put forward the "dividend irrelevance theory" in the 1960s, opening the academic study of dividend policy. Its follow-up studies are made through breaking the related assumptions and varieties of dividend theories are raised. Wang \& Qi (2005) point that the market effectiveness is the only assumption that is not thoroughly examined 40 -year after the appearance of "MM dividend irrelevance theory", that is, if the market is fully 
effective, the listed company's cash dividend policy is completely determined by the characteristics of the enterprise. Proportion of the United States to pay cash dividends of listed companies declined from $66.5 \%$ in 1978 to $20.8 \%$ in 1999. Fama \& French (2001) research this phenomenon to determine the relationship between enterprise characteristics and the cash dividend policy. They point that large number of smallscale listed companies with low profitability and strong growth opportunities change the overall characteristics of listed companies, which leads to the tendency to cash dividend reduction. However, after further consideration of characteristic elements of enterprise, all the companies are not willing to pay cash dividends. The propensity to pay cash dividends is low. Then low propensity to pay is determined by what factors, the traditional dividend theory does not seem to give a good answer.

Baker \& Wurglar (2004a) loosen the MM "efficient market hypothesis" of "the existence of the infinite arbitrage ensures that rational investors have no preference to dividends and capital gains". They point that there is only limited arbitrage in practice and put forward catering theory of dividends, that is, rational managers will make decisions on dividend payments starting from the preferences of investors. Baker \& Wurglar (2004b) further make use of 1963-2000 U.S. listed companies' dividend payments data to create the variable of "change to propensity to pay". The dividend premium of cashdividend-paying companies relative to non-cash-dividend-paying companies represents the variable of "catering incentives". They find that propensity to pay increases with positive dividend premium on the stock market and vice versa. The only exception was the Nixon administration froze dividend payment as a tool to curb inflation in January 1972 to April 1974. From the perspective of catering to investors' preference to cash dividend, catering theory of dividends explains the mystery of the disappearance of the dividend started in 1978 in the United State.

Catering theory of dividends better explains the cash dividend policy of the U.S. listed companies with relatively dispersed equity and stronger protection to small and medium-sized investors. Then in China, the equity is relatively concentrated and small and medium-sized investors' protection is weaker, whether the theory can explain the tendency of cash dividend payment? Chen (2003) uses event study method of excess return with data from 1995-2002 in Shenzhen Exchange. He discovers that dividend payout policy in Chinese market is related to investors' demand and many managers make policy timely to cater to investors' needs. Wang \& Qi (2005) use logit regression and linear regression method to show that whether to pay cash dividends is not determined by the characteristics of enterprise and is also not affected by investors' preference. Huang \& Shen (2007) conclude that catering theory of dividends does not apply to the decision of Chinese listed companies' cash dividend policy. Chinese listed companies have high concentrated ownership and a large number of non-tradable shares, which leads to that cash dividend policy of listed companies in China is not cater to small and medium-sized investors' dividend preference, but to meet the demand of the large shareholders.

Overall, the samples used in the researches on catering theory of dividends in China 
are mostly concentrated in front of completion of the non-tradable shares reform. As Huang \& Shen (2007) pointed out that before the completion of share reform, prevalence of high proportion of non-tradable shares in Chinese listed companies has a significant impact on the applicability of catering theory of dividends. Thus, based on the 2008-2014 data from listed companies, this paper analyzes whether cash dividend policy caters to investors' preference after the completion of non-tradable shares reform. This step involves analyzing the influence of business features on cash dividend policy, so we also talk about the characteristics of enterprises that pay out cash dividends.

This article is organized as follows. The first section is an introduction and literature review. The second section introduces research methods and data. In section three, the empirical test results are showed and the last section is the conclusion.

\section{Research Methods and Data}

\subsection{Research Assumptions and Methods}

\subsubsection{Relationships between Cash Dividend Policy and Enterprise Characteristics}

Fama \& French (2001) pointed out that corporate profitability, investment opportunities and firm size are three important factors that affect cash dividend policy. The stronger the profitability and the greater the scale, the more inclined to distribute cash dividends. One the contrary, companies tend to reduce cash dividend distribution facing more investment opportunities. Domestic previous research Xiao (2003) finds that profitability and cash dividend payment in the previous year has a positive relationship with cash dividend payment in the current year. The research range belongs to the completion before non-tradable shares reform and equity concentration has significant impact on cash dividend distribution. Reference the model from Fama \& French (2001), we build Probit model to investigate whether the characteristics affect their cash dividend policy after the non-tradable reform. The model is designed as follows:

$$
\operatorname{Pr}\left(\text { Payer }_{\mathrm{it}}=1\right)=\operatorname{probit}\left(\alpha+\beta_{1} \mathrm{MVP}_{\mathrm{it}}+\beta_{2} \frac{\mathrm{M}}{\mathrm{B}_{\mathrm{it}}}+\beta_{3} \frac{\mathrm{dA}}{\mathrm{A}_{\mathrm{it}}}+\beta_{4} \mathrm{ROA}_{\mathrm{it}}\right)
$$

$\mathrm{MVP}_{\text {it }}$ (Market Value Percentile) represents the proportion of company whose market value is no greater than the target company within the annual samples. It is used to measure the scale of listed companies. $\frac{\mathrm{M}}{\mathrm{B}_{\mathrm{it}}}$ represents the market-to-book ratio, measuring reinvestment opportunity. $\mathrm{ROA}_{\mathrm{it}}$ (return on asset) represents the profitability. $\frac{\mathrm{dA}}{\mathrm{A}_{\mathrm{it}}}$ represents growth rate of carrying amount of assets, reflecting the control variable of business development. The calculation method of each variable is shown in the table below: 


\begin{tabular}{|c|c|c|}
\hline & Variable Name & Variable Definitions \\
\hline Explained variable & Payer $_{\text {it }}$ & Payer $_{i t}=1$ represents company i pay cash dividends in year $t$; otherwise, Payer $_{i t}=0$ \\
\hline \multirow{7}{*}{ Explaining variable } & $\mathrm{MVP}_{\mathrm{it}}$ & $\frac{\text { amount of company whose market value is no greater than company } \mathrm{i} \text { in year } \mathrm{t}}{\text { total company }}$ \\
\hline & M & total market value of company $i$ at the end of year $t$ \\
\hline & & \\
\hline & $\mathrm{dA}$ & total asset of company $i$ at the end of year $t$ - total asset of company $i$ at the end of year $t-1$ \\
\hline & $\overline{\mathrm{A}_{\mathrm{it}}}$ & total asset of company $i$ at the end of year $\mathrm{t}-1$ \\
\hline & \multirow{2}{*}{$\mathrm{ROA}_{\mathrm{it}}$} & net profit of company $\mathrm{i}$ in year $\mathrm{t}$ \\
\hline & & average balance of total assets of company $\mathrm{i}$ in year $\mathrm{t}$ \\
\hline
\end{tabular}

\subsubsection{Whether Cash Dividend Policy Caters to Investors' Preference}

We learn from Wang \& Qi (2005) of the method, putting 2008-2014 data of listed companies in Shenzhen Exchange into the Probit model (1) and then calculate the estimated value of coefficients. After that, we put the data of listed companies in Shanghai Exchange into the Probit model, getting the theoretical value of cash dividends. We construct the variable of "propensity to pay" and construct $\triangle \mathrm{PTP}$ according to the following formula:

$$
\left.\Delta P T P_{t}=\left(A P R_{t}-T P R_{t}\right)-\left(A P R_{t-1}-T_{P R}\right)_{t-1}\right) .
$$

APR (actual payment ratio) represents the proportion of companies that pay cash dividend in actual. TPR (theoretical payment ratio) represents the proportion of companies that pay cash dividend in theory.

Baker and Wurgler (2004a) use dividend premium $\mathrm{P}^{\mathrm{D}-\mathrm{ND}}$ to reflect manager's motivation to cater to investors' cash dividend preference. It is constructed as follows:

$$
\mathrm{P}^{\mathrm{D}-\mathrm{ND}}=\overline{\left[\log \left(\frac{\mathrm{M}}{\mathrm{B}}\right)\right]^{\mathrm{D}}}-\overline{\left[\log \left(\frac{\mathrm{M}}{\mathrm{B}}\right)\right]^{\mathrm{ND}}} \text {. }
$$

The first term in the equation is the arithmetic mean of the logarithm of market-tobook ratio for the dividend-paying companies. The second term is the arithmetic mean of the logarithm of market-to-book ratio for the non-dividend-paying companies. If the cash dividend policy caters to investors' preference in Chinese listed companies, $\triangle \mathrm{PTP}$ will have a positive relationship with $\mathrm{P}^{\mathrm{D}-\mathrm{ND}}$.

\subsection{Sample and Descriptive Statistics}

In this paper, the sample data are taken from China Stock Market \& Accounting Research Database (CSMAR), ranging from 2008 to 2014. In the process of sample selection, we firstly exclude ST and ${ }^{\star}$ ST stock. Taking into account the special nature of the financial sector, we exclude all financial industry listed companies. We also exclude companies listed after 2007 to eliminate IPO effect. If listed companies are lack of any observed value, it is removed from the sample. Finally, the number of samples we get is $1209,1207,1191,1186,1195,1199,1158$ from 2008 to 2014 respectively. The sample 
composition and the number of companies paid cash dividend are shown in Table 1.

Mean test results in Table 2 show that significant differences of firm characteristics exist between cash-dividend-paying companies and non-cash-dividend-paying companies. Company that pays cash dividends has significantly larger size and less investment opportunities than non-cash-dividend-paying companies and this two enterprise characteristic difference are significant under $1 \%$ significant level. The profitability of cashdividend-paying companies is stronger than non-cash-dividend-paying companies at the significant level of $1 \%$. However, there is little difference of asset growth rate between the two kinds of companies. Results of the median test were approximately the same as the mean test results. From the perspective of descriptive statistics, there are significant differences between the two types of companies.

\section{Empirical Test Results}

\subsection{Test Results of the Relationship between Cash Dividend Policy and Firm Characteristics}

Probit regression is performed on all samples from 2008 to 2014 according to formula (1). Regression results in Table 3 show that the larger the size of the company, the more tendency to pay cash dividends under the significant level of $1 \%$. Companies with greater investment opportunities are more inclined to pay cash dividends, in additional to 2009 is significant under the $5 \%$ significant level, the rest of the year are significant under the $1 \%$ significant level. Besides, the stronger the profitability, the more inclined to pay cash dividends, and the impact is significant in 2009 at a significant level of 5\%, the rest of the year were significant at a significant level of $1 \%$. In addition, the impact of asset growth rate on cash dividends payment is significant only in 2009, 2012, 2013 and 2014. This impact is negative, that is, the higher asset growth rate, the faster the enterprise development and the less tendency to pay cash dividends.

$\mathrm{R}^{\wedge} 2$ value fluctuates at the level of about $20 \%$, suggesting that the characteristics of firm do not completely determine whether a listed company pay cash dividends or not. As to this, we can examine whether the part that is not explained represents managers cater to investors' dividend preference.

Table 1. Annual statistical results of the sample.

\begin{tabular}{cccccccc}
\hline Year & 2008 & 2009 & 2010 & 2011 & 2012 & 2013 & 2014 \\
\hline Total sample in Shenzhen Exchange & 487 & 489 & 480 & 480 & 483 & 492 & 467 \\
Total sample in Shanghai Exchange & 722 & 718 & 711 & 706 & 712 & 707 & 691 \\
Sum & 1209 & 1207 & 1191 & 1186 & 1195 & 1199 & 1158 \\
$\begin{array}{c}\text { Number of companies paid cash } \\
\text { dividend in Shenzhen Exchange }\end{array}$ & 236 & 239 & 254 & 267 & 297 & 315 & 289 \\
$\begin{array}{c}\text { Number of companies paid cash } \\
\text { dividend in Shanghai Exchange }\end{array}$ & 381 & 385 & 396 & 418 & 474 & 488 & 466 \\
$\quad$ Sum & 617 & 624 & 650 & 685 & 771 & 803 & 755 \\
\hline
\end{tabular}


Table 2. Descriptive statistics of enterprise characteristic value.

\begin{tabular}{|c|c|c|c|c|c|c|c|}
\hline \multirow{2}{*}{$\begin{array}{c}\text { Variable } \\
\text { Name }\end{array}$} & \multirow{2}{*}{ Year } & \multicolumn{3}{|c|}{ Mean value and mean value test } & \multicolumn{3}{|c|}{ Median and median test } \\
\hline & & payer & nonpayer & t-value & payer & nonpayer & $\mathrm{Z}$-value \\
\hline \multirow{7}{*}{ MVP } & 2008 & 0.6297 & 0.3654 & $17.8740^{* * *}$ & 0.6826 & 0.3364 & $15.8996^{* * *}$ \\
\hline & 2009 & 0.6155 & 0.3772 & $15.7206^{* * *}$ & 0.6607 & 0.3322 & $14.3264^{* * *}$ \\
\hline & 2010 & 0.6084 & 0.3707 & $15.4951^{* * *}$ & 0.6486 & 0.3342 & $14.1395^{\star * *}$ \\
\hline & 2011 & 0.6038 & 0.3591 & $15.8534^{* * *}$ & 0.6259 & 0.3117 & $14.4048^{\star \star *}$ \\
\hline & 2012 & 0.5723 & 0.3697 & $12.3170^{* * *}$ & 0.5975 & 0.3301 & $11.6062^{* * *}$ \\
\hline & 2013 & 0.5728 & 0.3536 & $13.2327^{\star * *}$ & 0.5947 & 0.2890 & $12.3646^{\star * *}$ \\
\hline & 2014 & 0.5721 & 0.3662 & $12.2839^{* * *}$ & 0.5967 & 0.3117 & $11.5579^{* \star *}$ \\
\hline \multirow{7}{*}{$\mathrm{M} / \mathrm{B}$} & 2008 & 1.6356 & 2.1621 & $-4.3393^{\star * *}$ & 1.3482 & 1.4286 & $-20.6787^{\star * *}$ \\
\hline & 2009 & 2.6355 & 4.4382 & $-3.9015^{\star * *}$ & 2.2651 & 2.5853 & $-7.3575^{\star * *}$ \\
\hline & 2010 & 2.6502 & 3.8264 & $-4.1636^{\star * *}$ & 2.1149 & 2.6592 & $-8.8177^{\star * *}$ \\
\hline & 2011 & 1.8126 & 2.8692 & $-4.8118^{\star \star \star}$ & 1.4723 & 1.7491 & $-17.5967^{\star * *}$ \\
\hline & 2012 & 1.6829 & 3.0576 & $-5.2479^{\star * *}$ & 1.4144 & 1.7159 & $-17.8255^{\star * *}$ \\
\hline & 2013 & 1.7960 & 3.2058 & $-4.9824^{\star * *}$ & 1.4586 & 1.7655 & $-17.3589^{* * *}$ \\
\hline & 2014 & 2.0925 & 3.5075 & $-4.9992^{\star * \star}$ & 1.7610 & 2.0376 & $-13.0626^{\star * *}$ \\
\hline \multirow{7}{*}{$\mathrm{dA} / \mathrm{A}$} & 2008 & 0.2031 & 0.0742 & $2.8368^{\star * *}$ & 0.1074 & 0.0067 & $10.7935^{* * *}$ \\
\hline & 2009 & 0.2419 & 0.2074 & 0.4744 & 0.1509 & 0.0382 & $10.3930^{* * *}$ \\
\hline & 2010 & 0.7668 & 0.2617 & 1.0600 & 0.1711 & 0.0687 & $9.4845^{\star * *}$ \\
\hline & 2011 & 0.4235 & 9.8063 & -1.1646 & 0.1437 & 0.0654 & $8.2069^{* * *}$ \\
\hline & 2012 & 0.3115 & 0.6079 & -1.1737 & 0.1079 & 0.0321 & $7.5533^{* * *}$ \\
\hline & 2013 & 0.5101 & 2.9009 & $-1.9502^{*}$ & 0.0966 & 0.0501 & $4.2960^{\star * *}$ \\
\hline & 2014 & 0.2143 & 1.2284 & $-1.7522^{\star}$ & 0.0947 & 0.0409 & $5.1281^{\star * *}$ \\
\hline \multirow{7}{*}{ ROA } & 2008 & 0.0633 & -0.0163 & $8.6237^{\star * *}$ & 0.0476 & 0.0071 & $18.9628^{\star * *}$ \\
\hline & 2009 & 0.0639 & -0.0005 & $13.2284^{* * *}$ & 0.0497 & 0.0140 & $16.1776^{* * *}$ \\
\hline & 2010 & 0.0689 & 0.0237 & $7.3388^{\star * *}$ & 0.0548 & 0.0210 & $15.2653^{* * *}$ \\
\hline & 2011 & 0.0658 & 0.0586 & 0.1988 & 0.0505 & 0.0149 & $15.2219^{* * *}$ \\
\hline & 2012 & 0.0503 & 0.0049 & $8.1814^{\star * *}$ & 0.0377 & 0.0074 & $15.4552^{* * *}$ \\
\hline & 2013 & 0.0500 & 0.0565 & -0.2940 & 0.0372 & 0.0092 & $13.9561^{\star \star *}$ \\
\hline & 2014 & 0.0497 & 0.0059 & $13.6817^{\star * *}$ & 0.0386 & 0.0082 & $15.5166^{* * *}$ \\
\hline
\end{tabular}

Payer represents the company paying cash dividends, nonpayer represents the company not paying cash dividends. The meaning of variables MVP, M/B, dA/A, ROA are consistent with the description in chapter 2.1.1. *, **, ${ }^{* * *}$ Represent the coefficient is significant at a significance level of $10 \%, 5 \%$ and $1 \%$ respectively. 
Table 3. Probit regression results of relationship between cash dividends payment and enterprise characteristics.

\begin{tabular}{|c|c|c|c|c|c|c|c|}
\hline & 2014 & 2013 & 2012 & 2011 & 2010 & 2009 & 2008 \\
\hline \multirow{2}{*}{ Constant } & 0.1588 & 0.0427 & $0.3430^{* * *}$ & $-0.3696^{\star * *}$ & $-0.4419^{\star * *}$ & -0.1488 & $-0.6903^{* * *}$ \\
\hline & $(1.4635)$ & $(0.4455)$ & (3.1929) & $(-3.5769)$ & $(-4.4922)$ & $(-1.3259)$ & $(-6.7872)$ \\
\hline \multirow{2}{*}{ mvp } & $1.1078^{* * *}$ & $1.7956^{* * *}$ & $1.3852^{* * *}$ & $2.0008^{* * *}$ & $1.8578^{* * *}$ & $1.3076^{\star *}$ & $2.1347^{\star * *}$ \\
\hline & (6.8934) & (12.1129) & (9.2425) & $(13.6212)$ & $(12.5766)$ & $(8.2766)$ & $(13.8870)$ \\
\hline \multirow{2}{*}{$\mathrm{M} / \mathrm{B}$} & $-0.2784^{\star * *}$ & $-0.2195^{\star * *}$ & $-0.4261^{\star * *}$ & $-0.2059^{* * *}$ & $-0.1598^{\star * *}$ & $-0.3466^{* * *}$ & $-0.2740^{\star * *}$ \\
\hline & $(-8.4763)$ & $(-6.8853)$ & $(-9.5082)$ & $(-5.8047)$ & $(-6.9609)$ & $(-10.1723)$ & $(-6.0870)$ \\
\hline \multirow{2}{*}{$\mathrm{dA} / \mathrm{A}$} & $-0.1077^{\star * *}$ & $-0.0058^{\star *}$ & $-0.0237^{\star \star}$ & -0.0179 & 0.0015 & $-0.1274^{\star}$ & -0.0308 \\
\hline & $(-2.9214)$ & $(-2.2052)$ & $(-1.7405)$ & $(-1.4987)$ & $(0.1960)$ & $(-1.9422)$ & $(-0.6645)$ \\
\hline \multirow{2}{*}{ ROA } & $13.2111^{\star * *}$ & $0.3336^{* * *}$ & $5.2781^{\star * *}$ & $0.3059^{* * *}$ & $2.2657^{\star * *}$ & $13.2249^{* *}$ & $3.5511^{\star * *}$ \\
\hline & (11.8367) & $(2.8507)$ & (9.3647) & (3.7543) & $(6.4944)$ & $(12.0261)$ & $(8.9954)$ \\
\hline $\begin{array}{c}\text { McFadden } \\
\text { pseudo- } R^{\wedge} 2\end{array}$ & 0.2545 & 0.1542 & 0.1945 & 0.1661 & 0.1786 & 0.2791 & 0.2226 \\
\hline Estrella $\mathrm{R}^{\wedge} 2$ & 0.3158 & 0.1914 & 0.2452 & 0.2192 & 0.2375 & 0.3645 & 0.2946 \\
\hline LR Ratio & 380.8255 & 234.5713 & 302.3092 & 268.3311 & 293.1763 & 466.6130 & 372.9675 \\
\hline Likelihood & -557.8966 & -643.3280 & -626.0429 & -673.5760 & -673.9554 & -602.6257 & -651.2727 \\
\hline nobs & 1158 & 1199 & 1195 & 1186 & 1191 & 1207 & 1209 \\
\hline
\end{tabular}

McFadden pseudo- $\mathrm{R}^{\wedge} 2$ and Estrella $\mathrm{R}^{\wedge} 2$ are $\mathrm{R}^{\wedge} 2$ value corresponding to the maximum likelihood estimation method. LR Ratio is likelihood ratio, Likelihood is likelihood probability, nobs is sample observation value. *, **,

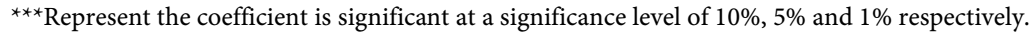

\subsection{Test Results of the Relationship between Cash Dividend Policy and Investors' Preference}

Probit regression is performed on samples from 2008 to 2014 in Shenzhen Exchange according to formula (1), getting the estimated values of coefficients, the estimated results is shown in Table 4. Then we put the 2008-2014 data of listed companies in Shenzhen Exchange into the formula (1) to obtain annual theoretical values of cash dividends. We calculate the average of annual theoretical values and get the theoretical cash dividends payment ratio. The actual cash dividends payment ratio is defined as the number of cash-dividend-paying companies divided by the total sample. Propensity to pay of the current year is calculated by subtracting theoretical cash dividends payment ratio from actual cash dividends payment ratio. The results of each year are shown in Table 5 .

It is shown in Table 5 that there is a big difference between theoretical cash dividends payment ratio and actual cash dividends payment ratio in Shanghai Exchange, and correlation is not strong. Theoretical cash dividends payment ratio is more stable than actual cash dividends payment ratio. Actual cash dividends payment ratio is rising 
Table 4. Probit regression results of Shenzhen Exchange listed companies.

\begin{tabular}{cccccc}
\hline & Constant & mvp & $\mathrm{M} / \mathrm{B}$ & $\mathrm{dA} / \mathrm{A}$ & $\mathrm{ROA}$ \\
\hline beta & $-0.3900^{* * *}$ & $1.8396^{* * *}$ & $-0.1246^{* * *}$ & $-0.0042^{*}$ & $0.2568^{* * *}$ \\
tstas & $(-7.3337)$ & $(21.4323)$ & $(-8.7604)$ & $(-1.9234)$ & $(4.9876)$ \\
McFadden pseudo-R^2 & & 0.1336 & \\
Estrella R^2 & & 0.1785 & \\
LR Ratio & & 618.7475 & \\
Likelihood & & -2006.3971 & \\
nobs & & 3378 & \\
\hline
\end{tabular}

McFadden pseudo- $\mathrm{R}^{\wedge} 2$ and Estrella $\mathrm{R} \wedge 2$ are $\mathrm{R} \wedge 2$ value corresponding to the maximum likelihood estimation method. LR Ratio is likelihood ratio, Likelihood is likelihood probability, nobs is sample observation value. *, ${ }^{* *}$, ${ }^{* * *}$ Represent the coefficient is significant at a significance level of $10 \%, 5 \%$ and $1 \%$ respectively.

Table 5. Annual propensity to pay of Shanghai Exchange listed companies.

\begin{tabular}{cccccc}
\hline Year & $\begin{array}{c}\text { Number of } \\
\text { Sample }\end{array}$ & $\begin{array}{c}\text { Number of } \\
\text { companies pay } \\
\text { cash dividends }\end{array}$ & APR (\%) & TPR (\%) & APR-TPR (\%) \\
\hline 2008 & 722 & 381 & $52.77 \%$ & $63.02 \%$ & $-10.25 \%$ \\
2009 & 718 & 385 & $53.62 \%$ & $57.81 \%$ & $-4.19 \%$ \\
2010 & 711 & 396 & $55.70 \%$ & $57.74 \%$ & $-2.04 \%$ \\
2011 & 706 & 418 & $59.21 \%$ & $61.57 \%$ & $-2.36 \%$ \\
2012 & 712 & 474 & $66.57 \%$ & $61.85 \%$ & $4.72 \%$ \\
2013 & 707 & 488 & $69.02 \%$ & $61.39 \%$ & $7.64 \%$ \\
2014 & 691 & 466 & $67.44 \%$ & $59.57 \%$ & $7.87 \%$ \\
\hline
\end{tabular}

since 2008. We calculate the first order difference of propensity to pay according to formula (2), and get the change of propensity to pay.

According to formula (3), we can obtain dividend premium in Shanghai Exchange, the calculation results are shown in Table 6. The dividend premium in Shanghai Exchange from 2008 to 2014 is negative. It seems that investors in China is not interested in cash dividends, that is, whether paying cash dividends is not related to investors' preference and has no effect on stock value.

Facing the feature of investors' dividend preference, whether managers will make corresponding cash dividend policy adjustments to cater to it? We construct the trend chart (Figure 1) to describe the correlation between change of propensity to pay and corresponding year dividend premium. Although dividend premium is negative, annual change of propensity to pay is positive. It shows that there are other factors that affect the policy decision of the listed corporation, excluding the influence of corporate characteristics. However, catering to investors' dividend preference is not within the 
Table 6. Dividend premium of Shanghai Exchange listed companies.

\begin{tabular}{cccc}
\hline Year & $\frac{\mathrm{M}^{\mathrm{D}}}{\mathrm{B}}$ & $\frac{\mathrm{M}^{\mathrm{ND}}}{\mathrm{B}}$ & Dividend Premium \\
\hline 2008 & 0.3685 & 0.4699 & -0.1014 \\
2009 & 0.7984 & 1.0807 & -0.2823 \\
2010 & 0.7558 & 1.0622 & -0.3064 \\
2011 & 0.4375 & 0.7367 & -0.2991 \\
2012 & 0.4142 & 0.7162 & -0.3021 \\
2013 & 0.4488 & 0.7310 & -0.2822 \\
2014 & 0.6114 & 0.8667 & -0.2552
\end{tabular}

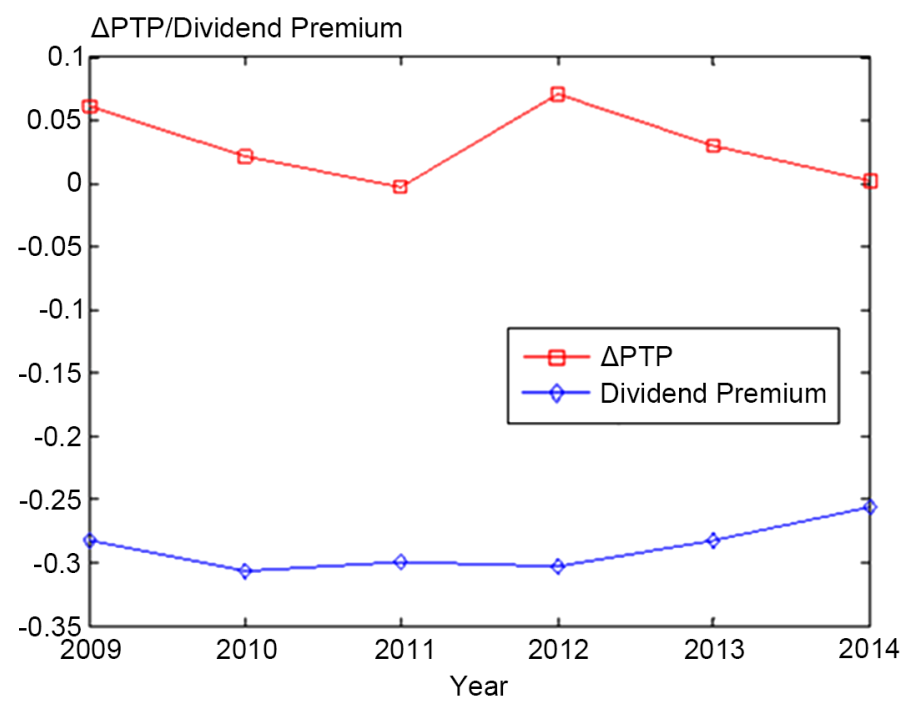

Figure 1. 2009-2014 change of propensity to pay and dividend premium in Shanghai Exchange.

scope of consideration. The two variables, dividend premium and change of propensity to pay, show totally opposite trend except in 2009. It is noteworthy that Huang \& Shen (2007) also find this feature in the study of the data before the non-tradable shares reform. Cash dividend policy cannot cater to small and medium-investors holding tradable shares and the reason can be attributed to the existence of a large number of non-tradable shares. Managers are more inclined to cater to the needs of major shareholders holding tradable shares.

However, we research the samples come after the non-tradable reform and the proportion of non-tradable shares drops dramatically. Compared with the results of Huang \& Shen (2007), we find that the negative dividend premium is more significant than that before the reform. Intuitive explanation may be that shareholders who originally hold non-tradable shares are less interested in the listed companies paying cash dividends when their holdings of shares can be traded. Hence, managers pay less attention to investors' dividend preference when making the cash dividend policy. 


\section{Research Conclusion}

Based on the 2008-2014 data from the listed companies in Shanghai and Shenzhen Exchange, we construct variables of propensity to pay, change of propensity to pay, and dividend premium. We discovered that dividend premium in Shanghai Exchange is negative during the period of 2008 to 2014, reflecting that investors do not care whether the company pays cash dividends. Compared with the trend of the change of propensity to pay and the corresponding dividend premium, the two variables show almost the opposite trend. It indicates that managers do not cater to investors' dividend preference when making cash dividend policy. Catering theory of dividends still does not seem to be a good explanation for the phenomenon of cash dividends paid by Chinese listed corporation after the completion of non-tradable reform.

\section{References}

Baker, M., \& Wurgler, J. (2004a). Appearing and Disappearing Dividends: The Link to Catering Incentives. Journal of Financial Economics, 73, 271-288.

http://dx.doi.org/10.1016/j.jfineco.2003.08.001

Baker, M., \& Wurgler, J. (2004b). A Catering Theory of Dividends. The Journal of Finance, 3, 1125-1165. http://dx.doi.org/10.1111/j.1540-6261.2004.00658.x

Chen, W. (2003). Analysis on the Evolution of Dividend Policy and Market Efficiency of Chinese Stock Market. In: The 12 th International Symposium on Empirical Accounting Research (Vol. 12, pp. 386-392).

Fama, E. F., \& French, K. R. (2001). Disappearing Dividends: Changing Firm Characteristics or Lower Propensity to Pay? Journal of Financial Economics, 60, 3-44. http://dx.doi.org/10.1016/S0304-405X(01)00038-1

Huang, J., \& Shen, Y. (2007). Dividend Policy Caters to Whose Need-Empirical Data from Chinese Listed Corporation. Accounting Studies, 8, 36-43.

Miller, M., \& Modigliani, F. (1961). Dividend Policy, Growth, and Valuation of Shares. Journal of Business, 10, 411-433. http://dx.doi.org/10.1086/294442

Wang, S., \& Qi, Y. (2005). An Empirical Analysis of the Cash Dividend and the Preference of Investors. Inquiry into Economic Issues, 12, 65-71.

Xiao, X. (2003). A Study on the Cash Dividend Policy of Chinese Listed Corporation. Doctoral Dissertation of Management Science, Beijing: Tsinghua University. 
Submit or recommend next manuscript to SCIRP and we will provide best service for you:

Accepting pre-submission inquiries through Email, Facebook, LinkedIn, Twitter, etc. A wide selection of journals (inclusive of 9 subjects, more than 200 journals)

Providing 24-hour high-quality service

User-friendly online submission system

Fair and swift peer-review system

Efficient typesetting and proofreading procedure

Display of the result of downloads and visits, as well as the number of cited articles

Maximum dissemination of your research work

Submit your manuscript at: http://papersubmission.scirp.org/

Or contact jfrm@scirp.org 